\title{
Studi kapasitas masyarakat sebagai mekanisme bertahan menghadapi bencana banjir di Desa Sitiarjo, Kecamatan Sumbermanjing Wetan, Kabupaten Malang
}

\author{
Mohamad Mambaus Su'ud ${ }^{1}$ dan Mashur Hasan Bisri ${ }^{2}$
}

Diterima 26 September 2019, Dipublikasikan 31 Oktober 2019

Cpenulis (2019)

\begin{abstract}
The aim of this study was to determine the capacity of communities as a mechanism to withstand floods Sitiarjo Village, District Sumbermanjing Wetan. This research is descriptive qualitative. The research phase was divided into three, i.e: (1) pre-field observation; (2) field observation; (3) data processing. The method used in data collection is FGD (Focused Group Disscusion) and in-depth interviews. The results of the study indicate that the community has a strong capacity in social, cultural, economic and government aspects in dealing with floods. In the socio-cultural aspect, the community develops a local early warning system through "titir" and a communication chain involving the community along the Panguluran watershed armed with traditional technology, as well as the mutual development of a public evacuation site in the form of multi-storey buildings, in addition to every family capable of building terraced houses . In addition, the community has the capacity to survive in saving economic assets by creating "plenggrongan" and planting calendar systems for crisis management. Diversification of plants such as planting bananas and sengon for daily use and annual savings when agricultural land was destroyed by flood.
\end{abstract}

\section{Keywords}

Capacity, Coping Mechanism, Flood, Sitiarjo

\section{PENDAHULUAN}

Desa Sitiarjo, Kecamatan Sumbermanjing Wetan, kabupaten Malang merupakan daerah yang berada di zona cekungan Malang Selatan, serta menjadi bagian dari DAS Penguluran. Desa Sitiarjo salah satu desa dengan potensi risiko bencana yang cukup besar. Dalam dokumen analisa risiko bencana Kabupaten Malang 2017, Desa Sitiarjo termasuk wilayah dengan berisiko bencana banjir bandang. Bila melihat sejarah kejadian bencana, memang dalam 15 tahun terakhir, banjir bandanglah ancaman bencana yang selalu hadir di wilayah Desa Sitiarjo. Mulai 2003, 2007, 2010, 2013, dan yang terbaru tahun 2017. Ke depan, sangat memungkinkan kejadian serupa berulang, terlebih lagi pola cuaca dan curah hujan yang fluktuatif dan cenderung ekstrim, akibat dari dampak perubahan iklim.

Banjir bandang 2003 cukup parah karena di tahun-tahun sebelumnya terjadi deforestasi hutan secara besar-besaran di wilayah Malang Selatan. Setelah itu, kejadian 2007 dan 2010 tidaklah terlalu besar lantaran proses peremajaan hutan sudah mulai berjalan. Dampak perubahan iklim mulai dirasakan dengan banjir bandang parah pada 2013 dengan dampak 925

$1 \quad$ Universitas Islam Raden Rahmat Malang suud.dien@gmail.com

2 Universitas Islam Raden Rahmat Malang 
KK dan 1 orang meninggal. Banjir kembali melanda pada tahun 2016, tercatat 231 rumah warga tergenang (Sumber: Inventaris Data Bencana BPBD Kab. Malang).

Sebagai upaya dalam menghadapi bencana akibat dampak perubahan iklim itu, setiap individu maupun masyarakat didorong untuk mampu mengembangkan kapasitas dengan berbagai sistem penyesuaian dalam merespon ancaman. Respon itu biasa bersifat jangka pendek yang disebut mekanisme penyesuaian (coping mechanism) atau dalam jangka panjang yang dikenal sebagai mekanisme adaptasi (adaptatif mechanism). Mekanisme dalam menghadapi perubahan dalam jangka pendek bertujuan untuk mengakses kebutuhan hidup dasar yaitu keamanan, sandang, dan pangan, sedangkan mekanisme jangka panjang bertujuan untuk memperkuat sumber-sumber kehidupannya.

Marschiavelli (2008) menyatakan bahwa mekanisme bertahan masyarakat terdiri atas mekanisme struktural dan non-struktural. Mekanisme bertahan tersebut dibagi menjadi tiga yaitu dalam hal (1) teknologi yang berkaitan dengan usaha menjaga harta benda, (2) ekonomi yang berkaitan dengan usaha memanfaatkan sumber daya yang ada, dan (3) sosial yang berkaitan dengan aktivitas dan tanggapan masyarakat saat menghadapi bencana. Prinsip kehatihatian dimulai dari mencermati setiap bagian kegiatan yang berpotensi menjadi ancaman terhadap keberadaan aset penghidupan dan jiwa manusia. Ancaman tersebut perlahan-lahan maupun tiba-tiba akan berpotensi menjadi sebuah bencana, sehingga menyebabkan hilangnya jiwa manusia, harta benda dan lingkungan.

Praktik-praktik penguatan kapasitas masyarakat dalam pengurangan risiko bencana (PRB), sering mengabaikan aspek lokalitas, pengetahuan cenderung disampaikan secara top down. Akibatnya pengetahuan itu tidak terinternalisasi ke dalam sosial budaya masyarakat. Sehingga studi ini dilakukan dengan tujuan untuk mengetahui secara mendalam kapasitas masyarakat sebagai mekanisme bertahan menghadapi bencana banjir Desa Sitiarjo, Kecamatan Sumbermanjing Wetan, agar dapat menjadi referensi para praktisi untuk melihat aspek lokalitas masyarakat.

\section{METODE}

Penelitian ini bersifat deskriptif kualitatif yaitu data disajikan dalam bentuk kata-kata atau gambar (Fraenkel dan Wallen, 1990 dalam Creswell, 2010). Tahap penelitian yang dilakukan dibagi menjadi tiga, yaitu: (1) pra-lapangan; (2) kerja lapangan; (3) pengolahan data. Tahap pralapangan meliputi tinjauan literatur, pengumpulan data pendukung, penetapan informan kunci, penyiapan alat bahan, persiapan kerja lapangan. Tahap kerja lapangan meliputi proses pengumpulan data berupa informasi dari masyarakat Sitiarjo yang terdiri atas unit rumah tangga, sektor swasta dan pemerintah desa yang diwakili oleh staf. Metode yang digunakan dalam pengumpulan data adalah FGD (Focused Group Disscusion) dan wawancara mendalam. Tahap pengolahan data yaitu analisis kapasitas sosial, ekonomi, dan budaya sebagai mekanisme bertahan dari masyarakat Siriarjo menghadapi banjir.

\section{HASIL DAN PEMBAHASAN}

Secara Geografis Desa Sitiarjo termasuk Daerah Aliran Sungai (DAS) Penguluran, berada di cekungan antara perbukitan Sidodai dengan perbukitan Karst formasi Wonosari (Gambar 1). DAS Penguluran sendiri memiliki luas sekitar $163 \mathrm{~km}^{2}$ dengan 8 anak sungainya; Kali 
Kedungbiru, Kali Kelaka, Kali Bangbang, Kali Bulubranjang, Kali Talangsari, Kali Kampungbaru, Kali Klepu dam Kali Ringinkembar.

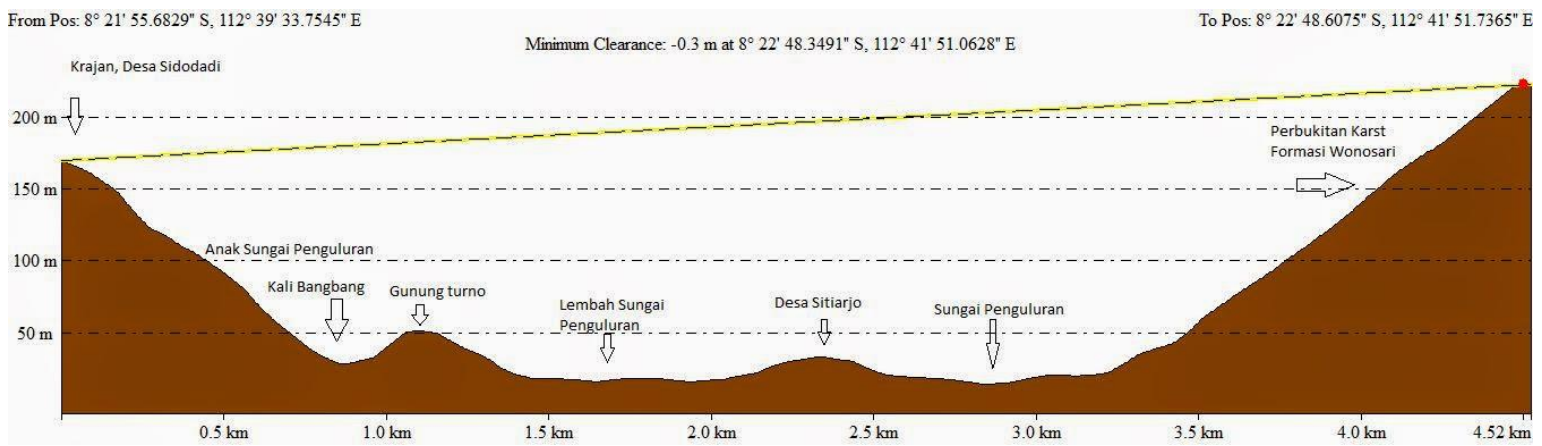

Gambar 1. Penampang Topogafi Desa Sitiarjo (Suara Geologi, diakses 2018)

Melihat kondisi topografi wilayah yang berada di zona cekungan Malang Selatan, serta menjadi bagian dari DAS Penguluran, Desa Sitiarjo salah satu desa dengan potensi risiko bencana yang tinggi. Dalam dokumen analisa risiko bencana Kabupaten Malang, termasuk wilayah dengan berisiko bencana banjir bandang. Bila melihat sejarah kejadian bencana, memang 15 tahun terakhir, banjir bandanglah ancaman bencana yang selalu hadir di wilayah Desa Sitiarjo. Mulai 2003, 2007, 2010, 2013, dan 2017 (Infografis 1).

\begin{tabular}{|c|c|c|c|c|}
\hline $\begin{array}{c}\text { November } 2003 \\
\text { Pukul 21.00-23.00 } \\
\text { WIB }\end{array}$ & $\begin{array}{c}26 \text { Desember } 2007 \\
\text { Pukul } 12.00-14.00 \\
\text { WIB }\end{array}$ & 2010 & $\begin{array}{c}\text { 9 Juli } 2013 \\
\text { Pukul 20.00 WIB }\end{array}$ & $\begin{array}{c}18 \text { Okt } 2017 \\
\text { Pukul } \\
08.00-12.00 \text { WIB } \\
13.00-15.00 \text { WIB } \\
15.00-17.00 \text { WIB }\end{array}$ \\
\hline 2003 & 2007 & 2010 & 2013 & 2017 \\
\hline $\begin{array}{l}\text { Ketinggian Air 1-3 } \\
\mathrm{m}\end{array}$ & $\begin{array}{l}\text { Ketinggian Air 1- } \\
2.5 \mathrm{~m}\end{array}$ & $\begin{array}{l}\text { Ketinggian Air 1- } \\
1.5 \mathrm{~m}\end{array}$ & $\begin{array}{l}\text { Ketinggian Air 1- } \\
3.5 \mathrm{~m}\end{array}$ & $\begin{array}{l}\text { Ketinggian Air 1- } \\
2.5 \mathrm{~m}\end{array}$ \\
\hline $\begin{array}{l}\text { Dampak: } \\
\text { - Korban jiwa } 3 \\
\text { orang } \\
\text { - Puluhan rumah } \\
\text { rusak } \\
\text { - Ratusan terendam } \\
\text { - 1 Balai dusun } \\
\text { rusak total } \\
\text { - 1 Sekolah Ruska } \\
\text { Total } \\
\text { - } 50 \text { m Jalan Rusak } \\
\text { - } 100 \text { m irigasi } \\
\text { rusak total } \\
\text { - Puluhan Ha } \\
\text { tanaman sawah } \\
\text { gagal panen } \\
\text { - Pasar terendam } \\
\text { - Puluhan ternak } \\
\text { sapi, kambing } \\
\text { hanyut }\end{array}$ & $\begin{array}{l}\text { Dampak: } \\
\text { - } 765 \text { rumah } \\
\text { terendam } \\
\text { - Pasar terendam } \\
\text { - } \text { Gagal panen di } \\
\text { seluruh dusun } \\
\text { Rowo terate } \\
\text { - } 2384 \text { jiwa } \\
\text { terdampak }\end{array}$ & $\begin{array}{l}\text { Dampak: } \\
\text { - } 700 \text { an rumah } \\
\text { terendam } \\
\text { - Pasar terendam } \\
\text { - Gagal panen }\end{array}$ & $\begin{array}{l}\text { Dampak: } \\
\text { - } \text { Korban jiwa } 1 \\
\text { orang } \\
\text { - Ratusan rumah } \\
\text { terendam } \\
\text { - } 63 \text { rumah rusak } \\
\text { berat } \\
\text { - } 200 \mathrm{~m} \text { irigasi } \\
\text { rusak berat } \\
\text { - Puluhan Ha } \\
\text { sawah gagal } \\
\text { panen, rusak } \\
\text { - Puluhan Ha } \\
\text { kebun pisang } \\
\text { pekarangan } \\
\text { rumah rusak } \\
\text { berat } \\
\text { - Pasar terendam } \\
\text { - Tanggul sungai } \\
\text { rusak }\end{array}$ & $\begin{array}{l}\text { Dampak: } \\
\bullet 1497 \text { jiwa/ } 537 \\
\text { KK terdampak } \\
\text { • Polowijen gagal } \\
\text { panen }\end{array}$ \\
\hline
\end{tabular}

Infografis 1. Sejarah Kejadian Bencana Banjir Bandang Desa Sitiarjo (Sumber: FGD, 2019) 
Banjir bandang 2003 cukup parah karena di tahun-tahun sebelumnya terjadi deforestasi hutan secara besar-besaran di wilayah Malang Selatan. Setelah itu, kejadian 2007 dan 2010 tidaklah terlalu besar lantaran proses peremajaan hutan sudah mulai berjalan. Dampak perubahan iklim mulai dirasakan dengan banjir bandang parah pada 2013, dan hampir terulang pada 2017. Bahkan menurut warga Dusun Rowoterate, ketinggian air banjir mencapai 3 meter (Gambar 2).

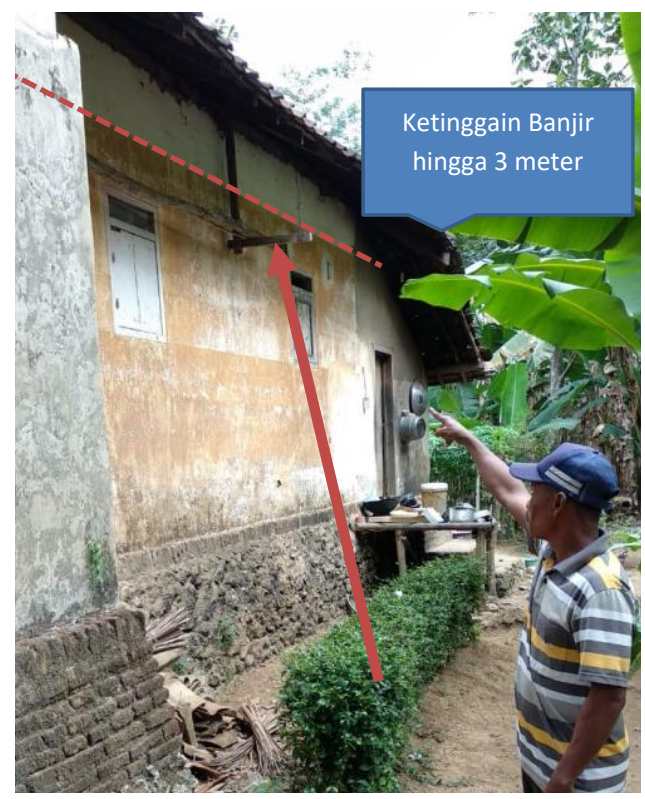

Gambar 2. Penampang Topogafi Desa Sitiarjo (Suara Geologi, diakses 2018)

\section{Mekanisme Bertahan pada Aspek Sosial-Budaya}

Banjir bagi masyarakat Sitiarjo, terutama warga Rowotrate telah menjadi bagian dari aspek kehidupan masyarakat. Menurut penuturan warga, banjir memang sudah terjadi sejak zaman kolonial Belanda. Pada awal 2000-an, pemerintah sebetulnya sempat merencanakan relokasi warga di wilayah yang aman dari banjir. Namun saat itu warga menolak karena sudah merasa sebagai tempat kelahiran dan tanah leluhur. Kejadian banjir yang terus berulang menjadikan warga perlahan mampu berperilaku adaptif dengan situasi itu. Perilaku adaptasi dalam kehidupan sehari-hari masyarakat merupakan wujud akumulasi pengalaman atau relasi masyarakat dengan alam (Purnomo dan Kurniawan, 2019), yang kemudian menjadi pengetahuan dan prinsip berperikehidupan masyarakat lokal secara turun-temurun (Maarif Syamsul. dkk. 2012).

Anggapan warga soal banjir tidak sama dengan anggapan teori banjir pada umumnya, banjir bukan dianggap lagi soal melimpahnya / meluapnya air akibat sungai yang tak lagi dapat menampung debit air, yang meskipun meluap $1 \mathrm{~cm}$ sudah dikategorikan sebagai banjir. Akan tetapi masyarakat Rowoterate menganggap luapan air menjadi banjir bila mencapai di atas lutut. Bila aliran sungai meluap, namun masih di bawah lutut, ini tak dianggap banjir, dan aktivitas masih berlangsung seperti sedia kala. Masyarakat juga menganggap bahwa banjir ini sebagai bentuk alam "membersihkan kotoran-kotoran" di lingkungan mereka. Selain juga warga percaya bahwa material yang di bawa banjir mampu menyuburkan tanah, sehingga pasca banjir hasil panen pertanian warga lebih melimpah.

Sistem peringatan dini menjadi komponen penting untuk situasi siaga bencana. Peringatan yang sedini mungkin kepada masyarakat dapat menentukan keputusan respon masyarakat, 
kapan waspada, kapan bersiaga, dan kapan harus evakuasi. International Strategy for Disaster Reduction/ ISDR menjelaskan bahwa, sistem peringatan dini harus memiliki 4 unsur; pertama, pengetahuan terhadap risiko bencana; kedua, pemantauan dan layanan peringatan; ketiga, penyebaran dan komunikasi; dan keempat, kemampuan respon (ISR. 2006).

Pengetahuan risiko bencana banjir bagi masyarakat Desa Sitiarjo, sudah menjadi bagian kehidupan masyarakat. Masyarakat sudah memahami bagaimana bencana dapat terjadi dari pengalaman sebelumnya (Purnomo, 2018). Misalnya dari penuturan warga, kejadian banjir bandang justru tidak diawali dari hujan di wilayah Sitiarjo, melainkan hujan yang ada di wilayah hulu (Desa Tegalrejo). Bahkan hujan dengan intensitas tinggi di wilayah Sitiarjo tidak menjadi penyebab banjir sama sekali. Oleh sebab itu, layanan informasi dan peringatan yang dibangun melibatkan masyarakat Desa Saat hujan dengan intensitas tinggi melanda Desa Tegalrejo, informasi akan disampaikan kepada beberapa tokoh masyarakat dan relawan di Desa Sitiarjo, karena secara empiris perhitungannya 2,5 - 3 jam kemudian air akan sampai di wilayah Sitiarjo. Wilayah yang terlanda terlebih dahulu ialah RW 15 Krajan Tengah, kemudian secara berurutan dan berselang 0,5-1 jam banjir akan menjalar ke wialayah RW 14 Krajan Kulon, RT 7 RW 2 Krajan Wetan, RW 3 Krajan Wetan, dan bermuara di Rowo Terate.

Bentuk penyebaran informasi dari rantai peringatan tersebut dilakukan dengan menyiagakan warga yang paling dekat dengan sungai, setiap ada perubahan ketinggian air sungai, petugas yang berjaga mengirim pesan berantai di wilayah yang lain (Gambar 3). Pesan disampaikan melalui sms handphone, handitalky, juga titir kentongan. Titir adalah ritme memukul kentongan secara terus-menerus, cepat tanpa jeda dengan tujuan semua masyarakat dapat mendengar dan merespon dengan segera. Respon masyarakat dilakukan dengan berbagai cara, penyelamatan ternak, penyelamatan harta benda, hingga penyelamatan diri.

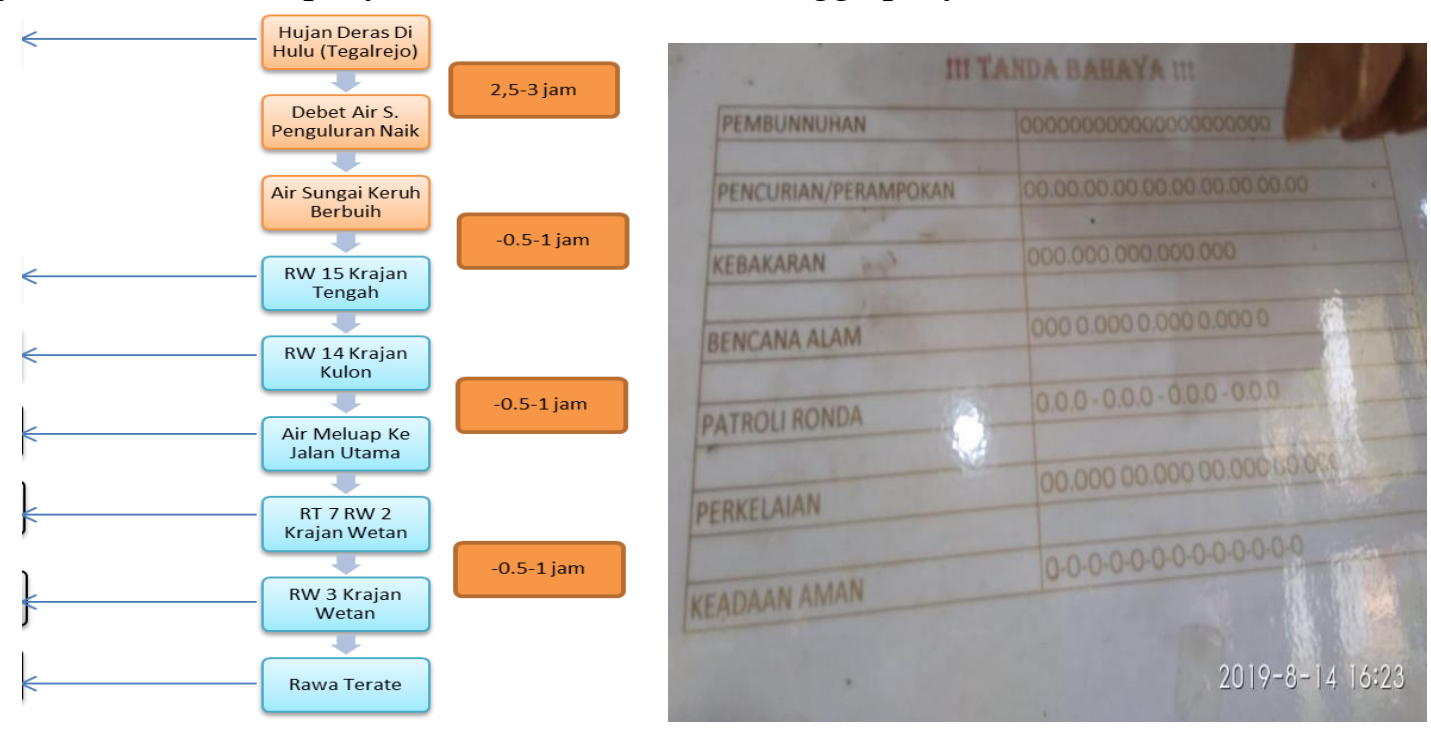

Gambar 3. Desain Sistem Peringatan Dini Banjir Bandang Sitiarjo (a), dan Kode Bunyi Titir untuk Bencana Alam (b) (Dokumentasi peneliti, 2019)

Saat peringatan banjir tersebar dan keadaan sudah dapat dipastikan akan terjadi banjir melalui pengamatan perubahan tinggi air di Sungai Penguluran, masyarakat telah siap untuk melakukan penyelamatan (evakuasi). Evakuasi dilakukan pada hewan ternak terlebih dahulu yang biasanya diikat di atas bukit (perengan) di belakang kampung Rowoterate. Sepanjang sehari semalam hewan ternak itu dibiarkan terikat hingga kondisi air benar-benar surut. Sementara, penyelamatan / evakuasi bagi warga sendiri bermacam-macam cara dilakukan. 
Beberapa warga lebih memilih tinggal di rumah masing-masing, yang sengaja memang telah ditinggikan rumahnya. Namun beberapa warga mengevakuasi diri ke tempat evakuasi komunal. Tempat evakuasi ini berada di Dusun Rowotrerate yang dibangun atas swadaya masyarakat di atas tanah hibah seorang warga. Dengan kapasitas 30-50 orang, tempat evakuasi ini dapat memfasilitasi warga yang rumahnya terendam hingga sampai atap saat banjir (Gambar 4).

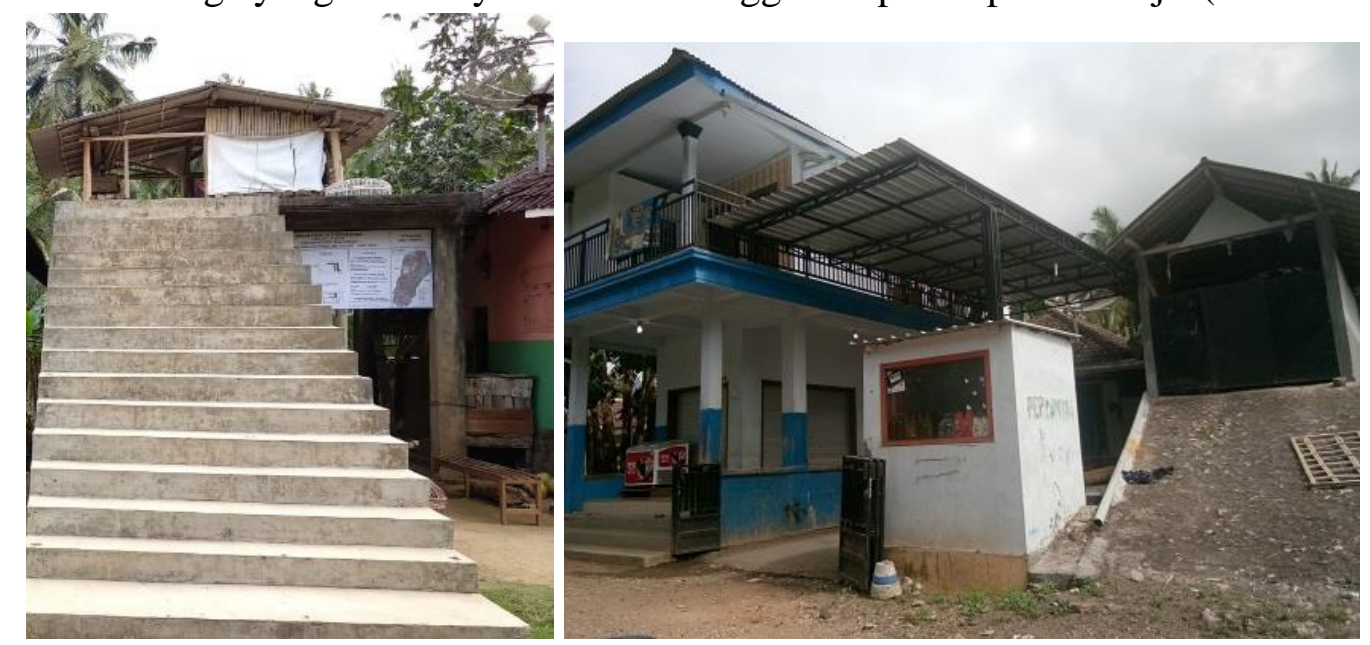

Gambar 4. Tempat evakuasi komunal (a) dan salah satu rumah warga yang didesain dua lantai, termasuk garasi rumah (b) (Dokumentasi peneliti, 2019)

\section{Mekanisme Bertahan Aspek Ekonomi}

Pada aspek ekonomi, beberapa pola aktivitas ekonomi masyarakat mengarah pada bagaimana dapat mempertahankan aset ekonomi dalam situasi banjir. Seperti dalam pemanfaatan lahan, selain untuk pertanian, warga juga memanfaatkan lahan untuk menanam sengon (Albizia chinensis). Sengon menjadi aset tabungan warga yang dapat dimanfaatkan dalam 3-5 tahun sekali. Tanaman ini memang cukup adaptif di wilayah rawa, atau wilayah dengan tingkat $\mathrm{pH}$ yang tinggi. Selain sawah padi dan sengon, masyarakat memanfaatkan lahan untuk menanam kelapa. Seperti halnya sengon, tanaman kelapa juga cukup adaptif menghadapi banjir, buahnya sering dimanfaatkan warga untuk berdagang di kawasan wisata pantai yang tak jauh dari wilayah Rowotrate. Cara-cara ini persis yang dijelaskan oleh Twigg (2004) bahwa mekanisme bertahan dalam masyarakat salah satunya ialah membangkitkan keanekaragaman sumber penghasilan, keanekaragaman produksi, tabungan, dan kredit.

Saat bencana banjir melanda, masyarakat Desa Sitiarjo memiliki mekanisme penyelamatan aset ekonomi dengan membuat "plenggrongan" sebagai bentuk kesiapsiagaan. Plenggorangan, adalah sejenis panggung yang terbuat dari papan kayu yang dipasang tepat di bawah kaki atap rumah, sehingga terdapat ruang diantara panggung dana tap rumah. Ruang tersebut dimanfaatkan untuk menyimpan cadangan bahan makanan seprti padi "gabah", jagung, singkong, dll. Saat banjir, "plenggrongan" juga berfungsi untuk menyelamatkan barang-barang rumah tangga, terutama barang elektronik. Di setiap rumah warga Rowoterate memiliki plenggrongan, terutama rumah yang hanya satu lantai (Gambar 5).

Cara bertahan yang ditunjukkan masyarakat Desa Sitiarjo dalam menghadapi banjir pada aspek ekonomi berkesesuaian dengan teori yang dijelaskan Adger (2006) bahwa kemampuan masyarakat untuk mampu bertahan dari perubahan dipengaruhi oleh keadaan sosial ekonominya, karakteristik kependudukan seperti penghasilan, kepemilikan aset, pendidikan, pekerjaan, ras, jenis kelamin dan suku (Yang, 2010). 

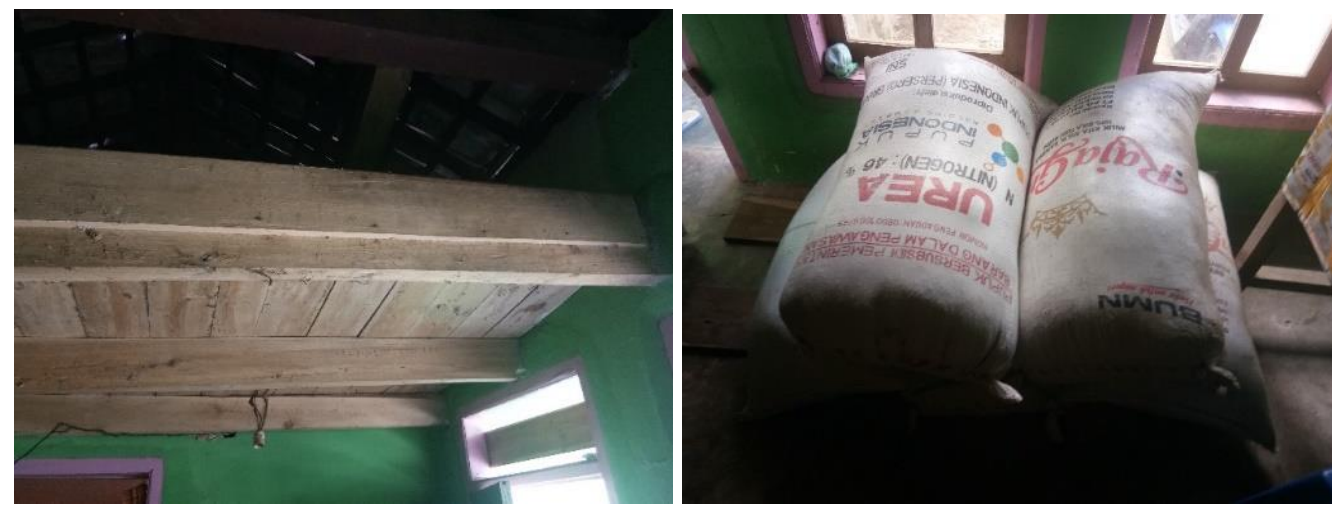

Gambar 5. Plenggrongan di Langit-Langit Rumah (a) dan Cadangan Makanan di simpan di Plenggrongan (b) (Dokumentasi peneliti, 2019)

\section{SIMPULAN}

Pengetahuan lokal dan mekanisme bertahan telah dimiliki masyarakat Sitiarjo yang terbentuk dari generasi ke generasi. Kapasitas tersebut membuat masyarakat mampu membantu memantau, menerjemahkan, dan menanggapi adanya perubahan di dalam lingkungan. Selain juga masyarakat mampu menyusun strategi untuk mengurangi dampak bencana banjir, baik secara individu maupun komunitas.

Penelitian ini perlu ditindaklanjuti dengan melakukan kajian kesiapsiagaan masyarakat pada unit-unit terkecil lagi di masyarakat misalnya pada tingkat keluarga, sekolah, dan kelompok agama. Dengan dilakukan kajian tersebut, akan dapat diketahui kapasitas masyarakat Desa Sitiarjo dalam menghadapi banjir secara lebih mendalam.

\section{DAFTAR PUSTAKA}

Bonye, S.Z. dan Godfred, J.S.. 2011. "Traditional Coping Mechanism in Disaster

Management in the Builsa and Sissala Districts of Northern Ghana", European Journal of

Social Science. Vol.25, No. 2, hal. 204-218

Creswell, John.W. 2010. Research Design, Pendekatan Kualitatif, Kuantitatif, dan Miked.

Yogyakarta: Pustaka Pelajar

Harsa Hastuadi. 2011. Pemanfaatan Sataid untuk Analisa Banjir Dan Angin Puting Beliung:

Studi Kasus Jakarta Dan Yogyakarta. Jurnal Meteorologi dan Geofisika volume 12 Nomor 2 - September 2011: 195 - 205. BMKG: Jakarta

Indrapertiwi C., Maghfirah N. 2015. Pola Adaptasi Masyarakat Terhadap Banjir Genangan di Sub DAS Celeng, Kabupaten Bantul. Jurnal Riset Kebencanaan Indonesia Vol. 1 No. 2, Oktober 2015

ISDR. 2006. Third International Conference on Early Warning, Membangun Sistem Peringatan Dini: Sebuah Daftar Periksa

Kusumaningtyas, P. 2007. Interpretasi Ulang Makna Spritual Bencana dalam Cerita Rakyat Indonesia. Kajian Politik Lokal dan Sosial. Vol.7, No. 1, hal. 167-184.

Maarif Syamsul. dkk. 2012, Kontestasi Pengetahuan dan Pemaknaan Tentang Ancaman Bencana Alam (Studi Kasus Ancaman Bencana Gunung Merapi), Jurnal Penanggulangan Bencana Volume 3 Nomor 1, Tahun 2012, hal. 1-13 
Mardikaningsih Sri Muliana, Muryani Catharina, Nugraha Setya. 2017. Studi Kerentanan Dan Arahan Mitigasi Bencana Banjir Di Kecamatan Puring Kabupaten Kebumen Tahun 2016. Jurnal GeoEco Vol. 3, No. 2 (Juli 2017) ISSN: 2460-0768

Marschiavelli, M.I.C.. 2008. Vulnerability Assessment and Coping Mechanism Related to Floods in Urban Areas: A Community Based Case Study in Kampung Melayu, Indonesia. Tesis : Universitas Gadjah Mada.

Paripurno, Eko Teguh.2010.Modul Manajemen Bencana Pengenalan Banjir untuk Penanggulangan Bencana. Yogyakarta: UPN Veteran

Purnomo, A. (2018) 'Pembangunan pengetahuan masyarakat di sekitar gunung api tentang risiko bencana erupsi’, Media Komunikasi Geografi. Universitas Pendidikan Ganesha, 19(1), p. 1. doi: 10.23887/mkg.v19i1.13610.

Purnomo, A. and Kurniawan, B. (2019) 'Dhamar Wulan and Menak Jinggo War; Mythological Interpretation on The Perception of Disaster Risk at Raung Eruption', IOP Conference Series: Earth and Environmental Science. IOP Publishing, 273, p. 012031. doi: 10.1088/1755-1315/273/1/012031.

Purwoko Alif, dkk. 2015. Pengaruh Pengetahuan Dan Sikap Tentang Resiko Bencana Banjir Terhadap Kesiapsiagaan Remaja Usia 15 - 18 Tahun Dalam Menghadapi Bencana Banjir Di Kelurahan Pedurungan Kidul Kota Semarang, Jurnal Geografi Volume 12 No 2

Slamet, Y. 2008. Metode Penelitian Sosial. Surakarta: LPP UNS dan UNS Press

Susandi Armi, dkk. 2016. Indeks Kerentanan Banjir Berbasis Prediksi Iklim Untuk Mitigasi Kebencanaan Banjir Jangka Panjang Di Daerah Aliran Sungai (Das) Bengawan Solo Flood Vulnerability Index Based On Climate Prediction For The Long Term Flood Disaster Mitigation Bengawan Solo Watershed, Jurnal Riset Kebencanaan Indonesia Vol. 2 No. 1, Mei 2016 